\title{
PEDAAGOGY
}

\section{Motivational and Value-Based Orientation of Pre-Conscription Youth toward Military Service}

\author{
LYUDMILA V. KOVTUNENKO \\ Scientific Research Institute of FSIN Russia, Moscow, Russian Federation \\ ORCID: https://orcid.org/0000-0002-0030-4536, e-mail: kovtunenkolv@mail.ru
}

\section{EGOR V. PARAMONOV}

Russian Air Force Military Educational and Scientific Center"Zhukovsky - Gagarin Air Force Academy", Voronezh, Russian Federation

ORCID: https://orcid.org/0000-0002-7819-0321, e-mail: egor_parampampam@ mail.ru

Abstract. Due to the collapse of the Soviet system of military professional orientation it has become necessary to review the work with pre-conscription youth oriented toward military service; the work, includes, among other things, expanding a network of cadet educational organizations. The main goals in forming the militaryprofessional orientation of pre-conscription youth are achieved by providing resources for the educational process, service and extracurricular activities. Motivational and valuebased attitude toward military service is developed throughout the entire educational period; this contributes to the formation of cadets' readiness to become career military officers and choose military service as a priority type of professional activity. Having analyzed psychological and pedagogical literature, we came to the conclusion that the system of military orientation of pre-conscription youth currently implemented in cadet corps, will contribute to the effective development of young people's orientation toward military service.

Key words: military service; motivational and value-based orientation; preconscription youth; cadets; cadet corps.

13.00.01 - General pedagogy, history of pedagogy and education (pedagogical sciences).

For citation: Kovtunenko L.V., Paramonov E.V. Motivational and value-based orientation of pre-conscription youth toward military service. Penitentiary Science, 2020, vol. 14, no. 4 (52), pp. 589-591. DOI 10.46741/2686-9764-2020-14-4-589-591.

The orientation toward military service among young people of pre-conscription age is formed and developed while they are preparing for military service. The main components of the formation and development of young people's orientation toward military service are as follows: motivation, high moral qualities of an individual, goals, interests, attitudes toward military service, and good physical fitness.

Today, the attitude toward military service prevailing in society in the late 1990s and early 2000s has changed dramatically. Russia's recovery from the crisis, the Russian Armed Forces reform, the rise of patriotism in society - all this indicates a recovery in the citizens' consciousness and, as a result, a change in their attitude toward the army and military service.

If earlier it was material benefit that dominated young people's motivation for enrolling in military universities, then today the social activity of youth is based on a conscious choice of military profession, the choice determined by 
patriotic ideas, civic stand and the desire to belong to the part of society that our country has been proud of throughout its entire history.

Following the ideas of A.F. Ioanidi we understand the orientation of pre-conscription youth toward military service as "a complex, integrative personal formation, the predominant components of which are motives, interests, value orientations, ideals and beliefs, manifested in a positive attitude and an active desire to fulfill one's civil and military duty" [1, p. 54].

The formation and development of the military-professional orientation of an individual is reflected in the works of I.A. Alyokhin, A.V. Barabanshchikov, V.P. Davydov, M.I. Dyachenko, L.A. Kandybovich, V.M. Korovin, N.F. Fedenko, and others. The topics of relevant modern research are as follows: development of militaryprofessional orientation of youth at the stage of choosing a military profession (I.B. Nagaev, P.A. Prozorov, 2007), development ofteambased communication in the training group of cadets in the process of professional development of the future officer (A.A. Vorob'ev, 2009), development of military-professional orientation of cadets at a military university (A.F. Ioanidi, 2013), orientation toward militaryprofessional activity (V.A. Gubin, A.L. Zagoryuev, 2013), motivational and value-based orientation of students toward professional activity (I.V. Klimenko, 2013), spiritual and moral education of cadets of military institutes according to the Russian army traditions (V.A. Sidorchuk, 2008), pedagogical system of youth training for military service (Yu.V. Trubin, 2015), formation of an active stand as a defender of the fatherland in cadets of military universities (V.S. Makarenko, 2018), etc.

However, dynamically changing social relations bring to the fore the research onthe formation and development of motivational and value-based orientation of pre-conscription youth toward military service.

Considering professional orientation as one of the significant factors in the formation and development of professionally important qualities of the future defender of the Motherland, we believe that it contributes to the comprehensive development of the citizen's personality.

The measures taken at the state level and aimed at popularization of military service seek to promote the military-professional orientation of pre-conscription youth, but they are nonrecurrent, often unsystematic, and require that the quality of the work carried out be improved considerably.

In practice, the development of children and young people's orientation toward military service should begin in school, then in cadet schools and Suvorov general education organizations, and then with cadets and students of military organizations of higher education.

Let us consider the formation of a militaryprofessional orientation on the example of cadet corps.

Cadet corps historically occupied a top priority place in the training of future officers. Cadet corps represented the primary level in the special military training of future officers and at the same time provided them with top-notch civilian education, allowing them to continue education in the most prestigious universities.

Cadet education is state education that includes components of the basics of military and civil service; it is provided to Russian citizens in the order of development of general secondary education of the state military or civil service, during training and education in cadet educational institutions from childhood [3].

Along with the formation and development of "citizenship, patriotism, devotion to duty, and other spiritual, moral and socially significant values in cadets, an important task was to instill in them the qualities, knowledge, skills and abilities required for military service" [2, p. 79].

Intellectual, cultural, moral, and physical education and development of students in cadet schools were viewed as priority areas of teachers' work there. Currently, educational process, service and extracurricular activities represent the main potential of the military-professional orientation of cadets. "The resource of educational activities is found in the content of academic disciplines, subject matter of research and educational work, organizational forms, methods and means of work, which are selected so as to address the issues related to military-professional orientation of cadets" $[1$, p. 24].

The formation of professional competence in the framework of cadet education raises interest in military service and increases the desire to expand knowledge and skills related to military service. Service activities related to studying in a cadet school and the basics of military service that cadets learn (daily duty, unity of command, strict subordination, order of conduct, etc.) contribute to the conscious formation of their motivation and strengthen their plans to serve in the military.

Scientific work expands the boundaries of educational programs and, depending on the interests and preferences of cadets, helps them extend their knowledge of military history and master various areas related to professional military activities. Participation of cadets 
in academic competitions and skills contests, business games, seminars and conferences on military topics, their involvement in scientific activities - all this develops their thinking and helps them form their own sphere of professionally oriented research interests [4, p. 1052].

Traditionally, the priority areas in the education of cadets included civic consciousness, patriotism, loyalty to military duty, high responsibility, and discipline. Today, these major spiritual, moral, and social values are being nurtured and developed in cadets.

An important role in the formation and development of motivational and value orientation toward military service belongs to patriotic educational events such as "The glory of those days will last forever", "The day to commemorate the heroes of the Fatherland", "Memory watch", "We will be worthy of the memory of our heroes", "Forever in the ranks", "Contemporary heroes", etc.

The orientation of cadets toward military service is largely determined by the social environment, professional community, psychological and pedagogical conditions of the cadet corps environment, and the organization of all subjects of the educational process in the context of military-professional orientation. But the success of the development of orientation toward military service depends on the subjectivity of the cadets themselves, their value orientations, life plans, goals, and needs.

A high level of moral values in the future will guarantee not only the successful acquisition of professional competencies, the desire for improvement of one's professional skills, but also conscientious serving in the military.

\section{REFERENCES}

1. Ioanidi A.F. et al. Razvitie voenno-professional'noi napravlennosti kursantov voennogo vuza: monografiya [Development of military-professional orientation of military university cadets: monograph]. Omsk: Omskoe knizhnoe izdatel'stvo, 2013. $215 \mathrm{p}$.

2. Kovtunenko L.V., Paramonov E.V. Military-professional training of pre-conscript youth in cadet educational organizations. Perspektivy nauki = Prospects of Science, 2019, no. 5 (116), pp. 178-181. (In Russ.).

3. Ob utverzhdenii Poryadka organizatsii i osushchestvleniya obrazovatel'noi deyatel'nostiv federal'nykh gosudarstvennykh obshcheobrazovatel'nykh organizatsiyakh so spetsial'nymi naimenovaniyami "prezidentskoe kadetskoe uchilishche", "suvorovskoe voennoe uchilishche", "nakhimovskoe voenno-morskoe uchilishche", "kadetskii (morskoi kadetskii) voennyi korpus" i v professional'nykh obrazovatel'nykh organizatsiyakh so spetsial'nym naimenovaniem "voenno-muzykal'noe uchilishche", nakhodyashchikhsya v vedenii Ministerstva oborony Rossiiskoi Federatsii, i priema v ukazannye obrazovatel'nye organizatsii: prikaz Ministra oborony Rossiiskoi Federatsii ot 21 iyulya 2014 g. № 515 [On approving the procedure for organizing and implementing educational activities in federal state educational organizations with special names "presidential cadet school", "Suvorov military school", "Nakhimov naval school", "cadet (sea cadet) military corps" and in professional educational organizations with the special name "military music school", which are under the jurisdiction of the Ministry of Defense of the Russian Federation, and admission to the specified educational organizations: Order 515 of the Minister of Defense of the Russian Federation dated July 21, 2014]. Available at: http:// rg.ru/2014/10/01/minoborony-dok.html (accessed March 31, 2020).

4. Sergeeva M.G., Vilkova A.V., Litvishkov V.M., Kovtunenko L.V., Lukashenko D.V., Klimova E.M. Technology and innovation in the development of cognitive activity. International Journal of Innovative Technology and Exploring Engineering, 2019, vol. 8, no. 12, pp. 1050-1055.

\section{INFORMATION ABOUT THE AUTHORS}

LYUDMILA V. KOVTUNENKO - Doctor of Sciences (Pedagogy), Associate Professor, senior researcher at the Scientific Research Institute of FSIN Russia, Moscow, Russian Federation. ORCID: https://orcid.org/0000-0002-0030-4536, e-mail: kovtunenkolv@mail.ru

EGOR V. PARAMONOV - instructor-engineer for field training, Russian Air Force Military Educational and Scientific Center "Zhukovsky - Gagarin Air Force Academy", Voronezh, Russian Federation. ORCID: https://orcid.org/0000-0002-78190321, e-mail: egor_parampampam@mail.ru 